\title{
Investigation of antibacterial resistance of aliphatic quarterly ammonium salts in polyrethane dispersions
}

\author{
C Irina V. Zhukova, ${ }^{1 *}$ Azat A. Girfanutdinov, ${ }^{1+}$ Bulat F. Gataullin, ${ }^{2+}$ \\ Ksenia V. Golovanova, ${ }^{2}$ Tatiana V. Vdovina, ${ }^{3 *}$ Rozalia F. Akchurina, ${ }^{3+}$ \\ and Alexander A. Tabachkov ${ }^{2} *$ \\ ${ }^{1}$ Department of "Medical Engineering". ${ }^{2}$ Department of "Technology of Synthetic rubber." \\ ${ }^{3}$ Department of "Industrial Biotechnology". Kazan National Research Technological University. \\ Karl Marx St., 68. Kazan, 420015. Russia. Phone: +7917275 1463.E-mail: zhukovka116@mail.ru
}

\begin{abstract}
*Supervising author; ${ }^{+}$Corresponding author
Keywords: quaternary ammonium salts (biocide), polyurethane dispersion, and bactericidal properties.
\end{abstract}

Abstract
In this work we investigated the possibility of using different structures of biocides to detect the stability of dispersion and the antibacterial properties of polyurethane water-dispersion coatings to combat the negative impact on materials, bio-damage, which can affect the quality of the human environment. This allows the use of polyurethane aqueous dispersions, where the constancy of aseptic conditions of quality is combined with good properties of polyurethane coatings. The oasheaters have been used in the first year of the 19th century to reduce the number of people. Coatings used dispe6rsionnye water-based polyurethane dispe6rsii complex poliefrov different structure (polietilenglikoladipinat, polietilenbutilenglikoladipinat, and polibutilenglikoladipinat polidietilenglikoladipinat) 2,4-diisocyanate, ionic agent and chain extenders, at a concentration of dry matter of $20-50 \%$ by weight. One of the most commonly used methods for determining the activity of antimicrobial agents is the method of diffusion of substances into agar. Evaluation of the activity of antimicrobial agents by this method is carried out according to the diameter of the zone of inhibition of growth of microorganisms (Escherichia Colli and Bacillus subtilis) on the surface of the substrate. As a result of the research, it was revealed that the actions of the used antimicrobial agents can be arranged in the following order: alkyltrimethylammonium chloride $>$ didecyldimethylammonium chloride $>$ dialkyldimethylammonium chloride. Maximum concentrations of biocides were found at which polyurethane dispersions are stable and do not coagulate: for quaternary amine compounds with one alkyl, the maximum permissible concentration is $10 \%$, with dialkyl the maximum permissible concentration is $7.5 \%$, with trialkyl the maximum permissible concentration is 3\%. The increase in the diameter of the suppression of the growth of microorganisms is also influenced by the concentration of the polyurethane dispersion, which makes it possible to introduce antibacterial compounds much more.

\section{References}

[1] H.R. Ravikumar, S.S. Rao, C.S. Karigar. Biodegradation of paints: a current status. Indian J. Science and Technology. 2012. Vol.5. No.1. P.1977-1987.

[2] V.I. Solomatov, V.T. Erofeev, V.F. Smirnov and others. Biological resistance of materials. Saransk: Mordovia University Press. 2001. 195p. (russian)

[3] H.A. Sabev, S.M. Barratt, M. Greenhalgh et al. Biodegradation and biodeterioration of man-made polymeric materials. In: Fungi in biogeochemical cycles. 2006. P.212-235.

[4] O.F. Obidi, O.O. Aboaba, M.S. Makanjuola et al. Microbial evaluation and deterioration of paints and paint-products. J. Environmental Biology. 2009. Vol.30. No.5. P.835-840.

[5] V.T. Erofeev, V.F. Smirnov, E.A. Morozov. Microbiological destruction of materials. Moscow: Publishing house of the Association of construction universities. 2008. 125p. (russian)

[6] A.V. Ignatenko. Methods of monitoring the activity and effectiveness of antimicrobial drugs. Resource and energy-saving technologies and equipment, environmentally friendly technologies: materials of the Intern. scientific and technical Conf., Minsk, 19-20 Nov. 2008: at 2 pm. Belarusian. State Tehnol. Un-tMinsk. 2008. Iss.2. P.203-206. (russian)

[7] G. McDonnell, A.D. Russell. Antiseptics and Disinfectants: Activity, Action, and Resistance. Clinical Microbiology Reviews. 1999. Vol.12(1). P.147-179. 
INVESTIGATION OF ANTIBACTERIAL RESISTANCE OF ALIPHATIC QUARTERLY AMMONIUM SALTS... 128-132

[8] G.R. Nikolaenko, G.N. Kulevtsov, S.N. Stepin. The use of polyurethane dispersions. Bulletin of Kazan Technological University. 2012. https://cyberleninka.ru/article/v/primenenie-poliuretanovyh-dispersiy-votdelochnyh-protsessah-kozhevennoy-promyshlennosti

[9] E.L. Pehtasheva, A.N. Neverov, G.E. Zaikov, S.A. Shevtsova, N.E. Temnikova. Ways to protect materials from bio-damage. Bulletin of Kazan Technological University. 2012.

[10] MUK 4.2.1890-04 Determination of the microorganisms sensitivity to antibacterial substances: Methodical instructions. Moscow: Federal Center for State Sanitary and Epidemiological Surveillance of the Ministry of Health of Russia. 2004. 91p. (russian) 